\begin{tabular}{|c|c|c|c|}
\hline Case Reports $i$ & \multicolumn{2}{|c|}{ Case Rep Gastroenterol 2019;13:58-65 } & \multirow[b]{2}{*}{$\begin{array}{l}\text { Karger } \\
\text { Open access }\end{array}$} \\
\hline Gastroenterology & $\begin{array}{l}\text { DOI: 10.1159/000495604 } \\
\text { Published online: February 13, } 2019\end{array}$ & $\begin{array}{l}\text { (c) } 2019 \text { The Author(s) } \\
\text { Published by S. Karger AG, Basel } \\
\text { www.karger.com/crg }\end{array}$ & \\
\hline & $\begin{array}{l}\text { This article is licensed under the } \\
\text { International License (CC BY-NC) } \\
\text { Usage and distribution for commerci }\end{array}$ & $\begin{array}{l}\text { nons Attribution-NonCommercial } 4.0 \\
\text { ger.com/Services/OpenAccessLicense) } \\
\text { uires written permission. }\end{array}$ & \\
\hline
\end{tabular}

\title{
Primary Gastrointestinal Stromal Tumor of the Liver with Cystic Changes
}

\author{
Takashi Tashiro Fumihiro Uwamori Yukiomi Nakade Tadahisa Inoue \\ Yuji Kobayashi Tomohiko Ohashi Masashi Yoneda \\ Division of Gastroenterology, Department of Internal Medicine, Aichi Medical University, \\ Nagakute, Japan
}

\section{Keywords}

Gastrointestinal stromal tumors - Positron emission tomography/computed tomography . Primary gastrointestinal stromal tumor $\cdot$ Liver

\begin{abstract}
Gastrointestinal stromal tumors (GISTs) are known to originate specifically from the intestinal cells of Cajal located in the gastrointestinal mesenchyme. GISTs developing outside of the digestive tract have barely been reported. We encountered a first case of large primary GISTs in the liver with cystic changes. A 63-year-old man with a past history of brain infarction visited our hospital. The computed tomography $(\mathrm{CT})$ revealed a $6-\mathrm{cm}$ and a $10-\mathrm{cm}$ mass in the right and the caudal lobe of the liver, respectively. These tumors have marginal enhancement in the arterial phase; however, they presented as hypodense in the internal tumor sites. Both liver tumors had cystic changes. Gastrointestinal examinations using endoscopy revealed no other gastrointestinal tumors, and $\left[{ }^{18} \mathrm{~F}\right]$-fluoro-2-deoxy-D-glucose positron emission tomography/CT revealed multiple bone metastases in addition to the liver tumors. The liver tumor specimens were composed of spindle cells, and the immunohistochemical staining for c-Kit and for DOG1, as discovered on GIST, was positive. The patient was diagnosed with primary hepatic GIST with cystic changes.

(C) 2019 The Author(s)

Published by S. Karger AG, Basel
\end{abstract}


Tashiro et al.: Primary Gastrointestinal Stromal Tumor of the Liver with Cystic Changes

\section{Introduction}

Gastrointestinal stromal tumors (GISTs) are thought to have their origin in the interstitial cells of Cajal (ICCs) located in the gastrointestinal mesenchyme [1]. ICCs are morphologically characterized by a spindle- or stellate-shaped body, a thin perinuclear cytoplasm elongated into numerous long branching processes [1]. The most commonly used method to identify ICCs relies on the immunohistochemical detection of c-Kit, a transmembrane tyrosine kinase receptor [1]. GISTs are thought to arise from the gastrointestinal tract, including the esophagus, stomach, small intestine, and colon, and are diagnosed by immunohistochemical criteria, i.e., the expression of c-Kit [2].

Recently, GISTs originating not only from the gastrointestinal tract but also from extragastrointestinal sites have been reported [3]. Uterine GISTs, gallbladder GISTs, and pancreas GISTs have been reported [4-6]. With regard to the hepatobiliary system, Ortiz-Hidalgo et al. [5] reported that ICCs were present in the human gallbladder, and this has been definitively confirmed [7]. Furthermore, it has been suggested that ICCs were present in the human extrahepatic bile duct [8].

Although no ICCs have presented in human hepatocytes, primary hepatic GISTs have been barely reported [9]. Almost all cases of primary hepatic GISTs were resected because they had no distal metastasis [9]. On the other hand, few cases of primary hepatic GISTs with cystic changes have been reported in the literature. Here, we report a first case of GIST in the liver, which was accompanied by cyst formation.

\section{Case Presentation}

A 63-year-old man complained of epigastric discomfort and appetite loss and was admitted to the Department of Gastroenterology at our hospital. He had a medical history of leftsided cerebral infarction. No remarkable familial history existed. Upon physical examination, his height and weight were determined to be $167 \mathrm{~cm}$ and $71 \mathrm{~kg}$, respectively. His liver and spleen were not palpable. Laboratory tests revealed a white blood cell count of $11.4 \times 10^{3} / \mu \mathrm{L}$ and elevated levels of C-reactive protein $(1.06 \mathrm{mg} / \mathrm{dL})$. Serum $\alpha$-fetoprotein and protein induced by vitamin $\mathrm{K}$ absence/antagonist-II (PIVKA-II) were within normal limits.

Magnetic resonance imaging (MRI) revealed a low-intensity lesion on T1-weighted imaging (WI) and a high-intensity lesion on T2-WI in the caudal lobe, and it also revealed a lowintensity lesion on T1-WI and a high-intensity lesion on T2-WI in the right lobe. The diameter of the tumor in the caudal lobe was $10 \mathrm{~cm}$ and that in the right lobe was $6 \mathrm{~cm}$. Both liver tumors were marginally enhanced on T1-WI after gadolinium ethoxybenzyl diethylenetriaminepentaacetic acid administration (Gd-EOB-DTPA), and the interior of the tumors revealed a homogenous low-signal intensity (Fig. 1a). They were hypointense on hepatobiliary phase images on Gd-EOB-DTPA (Fig. 1b). A dynamic computed tomography scan showed that both liver tumors were marginally contrasted in high density in the early phase and that they were contrasted in iso-density in the late phase, and the internal sites of both tumors showed low-density areas (Fig. 2a, b). [18F]-fluoro-2-deoxy-D-glucose (FDG)-positron emission tomography (PET) revealed not only focal FDG uptake in the liver tumors but also multiple focal FDG uptakes in bones (Fig. 3). From these findings, the liver tumors were suspected to be malignant tumors with cystic changes and bone metastasis. The patient underwent ultrasonographyguided liver tumor biopsy. Serous fluid was not aspirated from the cystic lesion of the tumor. Microscopic findings showed that the liver specimens were composed of spindle cells with 


\section{Case Reports in Gastroenterology}

Case Rep Gastroenterol 2019;13:58-65

DOI: $10.1159 / 000495604$

(c) 2019 The Author(s). Published by S. Karger AG, Basel www.karger.com/crg

Tashiro et al.: Primary Gastrointestinal Stromal Tumor of the Liver with Cystic Changes

pleomorphic nuclei arranged into short fascicles (Fig. 4a). The liver tumor immunohistochemical staining for c-Kit and for DOG1, as discovered on GIST, was positive (Fig. 4b, c). These findings indicated the presence of GISTs in the liver.

To investigate the origin of the liver tumors, we performed upper and lower gastrointestinal endoscopy. The upper and lower endoscopic findings showed that there were no other malignant tumors contributing to liver and bone metastases. Due to these findings, our results led to a diagnosis of primary GIST in the liver with cystic changes.

\section{Discussion}

GISTs are known to arise from a pacemaker cell, such as the ICC [1], and can occur in the gastrointestinal tract, i.e., the esophagus, stomach, small intestine, and colon [2]. Recently, GISTs originating from outside of the gastrointestinal tract have been reported [3]. They can occur in the uterus, gallbladder, pancreas, and urinary bladder $[4,5,10,11]$. Although several GISTs arising from outside of the gastrointestinal tract have been reported [4-6], they represent only $1 \%$ of all GISTs of defined origin [12]. Concerning the hepatobiliary system, only 9 cases including the clinicopathological features and the treatment outcomes of primary hepatic GISTs have been reported [9]. Eight of 9 cases were resected, and the other case underwent radiofrequency ablation [9].

To examine the aspect of a hepatic tumor, imaging modalities play a pivotal role. MRI was performed in 3 cases; however, no characteristic findings were obtained [9]. FDG-PET was performed in 3 patients with hepatic GISTs, and high accumulation of FDG was found in hepatic tumors. The majority of GISTs present heterogenous enhancement of contrast agents [13]. Previous reports have shown that hepatic metastases from GISTs were heterogenous, hypodense lesions with progressive, concentric enhancement [13]. In the present case, GISTs were marginally contrasted in high density in the early phase and were contrasted in iso-density in the late phase. This indicates that our case is similar to hepatic metastasis from GISTs, which reveals concentric enhancement.

The main concern about GISTs in an unusual location has been whether the tumor is genuinely a primary tumor outside of the gastrointestinal tract or a metastasis from the gastrointestinal tract. The most common metastatic sites of GISTs of the gastrointestinal tract are the liver and peritoneum $[14,15]$. Our case showed that the histological and immunohistochemical findings strongly supported the diagnosis of GIST, and the radiological findings revealed that these tumors were located in the liver. Furthermore, the examination with upper and lower endoscopy revealed no tumors in the gastrointestinal tract. These findings support the manifestation of primary hepatic GISTs.

GISTs usually form a solid mass, sometimes presenting with focal cysts or calcification; however, GISTs rarely present with predominantly cystic changes. In GISTs from the gastrointestinal tract, tumors with regions of hemorrhage or necrosis may contribute to large cystic spaces [16], and GISTs often reveal extensive cystic changes in response to treatment with tyrosine kinase inhibitors $[17,18]$. In our case, the diameters of the tumors were 10 and $6 \mathrm{~cm}$, and almost the entire tumor volumes were occupied by a cystic lesion. However, serous fluid was not aspirated from the tumors when the patient underwent liver biopsy, and the patient had not undergone any treatment before our diagnosis. The reason for extensive cystic formation constituting the major portion of the GISTs thus remains unclear. During tumor progression, massive necrotic changes of tumor cells might have occurred [19]. 
In conclusion, we describe a first case of primary hepatic GISTs with cystic formation. Tumors with regions of hemorrhage or necrosis might contribute to large cystic spaces.

\section{Statement of Ethics}

Consent was obtained from the patient for the publication of this case report.

\section{Disclosure Statement}

All authors declare no conflicts of interest.

\section{References}

1 Fletcher CD, Berman JJ, Corless C, Gorstein F, Lasota J, Longley BJ, et al. Diagnosis of gastrointestinal stromal tumors: A consensus approach. Hum Pathol. 2002 May;33(5):459-65.

2 Miettinen M, Lasota J. Gastrointestinal stromal tumors-definition, clinical, histological, immunohistochemical, and molecular genetic features and differential diagnosis. Virchows Arch. 2001 Jan;438(1):1-12.

3 Reith JD, Goldblum JR, Lyles RH, Weiss SW. Extragastrointestinal (soft tissue) stromal tumors: an analysis of 48 cases with emphasis on histologic predictors of outcome. Mod Pathol. 2000 May;13(5):577-85.

4 Wingen CB, Pauwels PA, Debiec-Rychter M, van Gemert WG, Vos MC. Uterine gastrointestinal stromal tumour (GIST). Gynecol Oncol. 2005 Jun;97(3):970-2.

5 Ortiz-Hidalgo C, de Leon Bojorge B, Albores-Saavedra J. Stromal tumor of the gallbladder with phenotype of interstitial cells of Cajal: a previously unrecognized neoplasm. Am J Surg Pathol. 2000 Oct;24(10):1420-3.

6 Meng L, Fang SH, Jin M. An unusual case of pancreatic and gastric neoplasms (2010: 12b). Malignant GISTs originating from the pancreas and stomach. Eur Radiol. 2011 Mar;21(3):663-5.

7 Hinescu ME, Ardeleanu C, Gherghiceanu M, Popescu LM. Interstitial Cajal-like cells in human gallbladder. J Mol Histol. 2007 Aug;38(4):275-84.

8 Ahmadi O, Nicholson ML, Gould ML, Mitchell A, Stringer MD. Interstitial cells of Cajal are present in human extrahepatic bile ducts. J Gastroenterol Hepatol. 2010 Feb;25(2):277-85.

9 Nagai T, Ueda K, Hakoda H, Okata S, Nakata S, Taira T, et al. Primary gastrointestinal stromal tumor of the liver: a case report and review of the literature. Surg Case Rep. 2016 Dec;2(1):87.

10 Lang RJ, Klemm MF. Interstitial cell of Cajal-like cells in the upper urinary tract. J Cell Mol Med. 2005 JulSep;9(3):543-56.

11 Popescu LM, Hinescu ME, Ionescu N, Ciontea SM, Cretoiu D, Ardelean C. Interstitial cells of Cajal in pancreas. J Cell Mol Med. 2005 Jan-Mar;9(1):169-90.

12 Miettinen M, Lasota J. Gastrointestinal stromal tumors: pathology and prognosis at different sites. Semin Diagn Pathol. 2006 May;23(2):70-83.

13 Vanel D, Albiter M, Shapeero L, Le Cesne A, Bonvalot S, Le Pechoux C, et al. Role of computed tomography in the follow-up of hepatic and peritoneal metastases of GIST under imatinib mesylate treatment: a prospective study of 54 patients. Eur J Radiol. 2005 Apr;54(1):118-23.

14 DeMatteo RP, Lewis JJ, Leung D, Mudan SS, Woodruff JM, Brennan MF. Two hundred gastrointestinal stromal tumors: recurrence patterns and prognostic factors for survival. Ann Surg. 2000 Jan;231(1):51-8.

15 Gupta P, Tewari M, Shukla HS. Gastrointestinal stromal tumor. Surg Oncol. 2008 Aug;17(2):129-38.

16 Levy AD, Remotti HE, Thompson WM, Sobin LH, Miettinen M. Gastrointestinal stromal tumors: radiologic features with pathologic correlation. Radiographics. 2003 Mar-Apr;23(2):283-304, 456; quiz 532.

17 Chourmouzi D, Sinakos E, Papalavrentios L, Akriviadis E, Drevelegas A. Gastrointestinal stromal tumors: a pictorial review. J Gastrointestin Liver Dis. 2009 Sep;18(3):379-83.

18 Bechtold RE, Chen MY, Stanton CA, Savage PD, Levine EA. Cystic changes in hepatic and peritoneal metastases from gastrointestinal stromal tumors treated with Gleevec. Abdom Imaging. 2003 NovDec;28(6):808-14.

19 Wang L, Liu L, Liu Z, Tian Y, Lin Z. Giant gastrointestinal stromal tumor with predominantly cystic changes: a case report and literature review. World J Surg Oncol. 2017 Dec;15(1):220. 


\section{Case Reports in Gastroenterology}

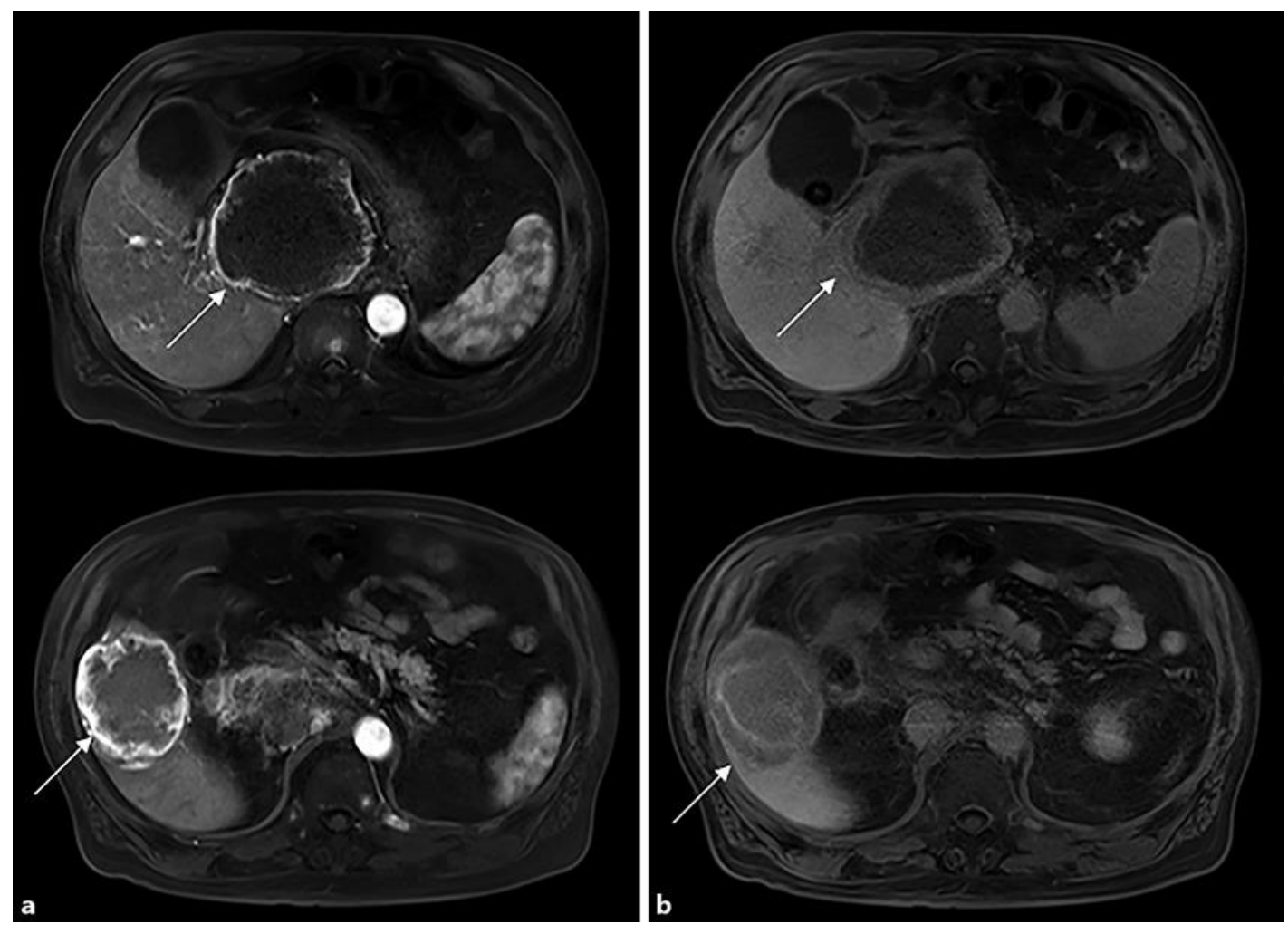

Fig. 1. a Magnetic resonance imaging revealed that the liver tumors in the right and the caudal lobes were marginally enhanced on T1-weighted imaging after gadolinium ethoxybenzyl diethylenetriaminepentaacetic acid administration (Gd-EOB-DTPA), and the interior of the tumors revealed homogenous low-signal intensity. b Both liver tumors were hypointense on hepatobiliary phase images on Gd-EOB-DTPA. Arrows indicate the liver tumors. 


\section{Case Reports in Gastroenterology}

\begin{tabular}{l|l}
\hline Case Rep Gastroenterol 2019;13:58-65 \\
\hline DOI: 10.1159/000495604 & $\begin{array}{l}\text { @ 2019 The Author(s). Published by S. Karger AG, Basel } \\
\text { www.karger.com/crg }\end{array}$ \\
\hline
\end{tabular}

Tashiro et al.: Primary Gastrointestinal Stromal Tumor of the Liver with Cystic Changes
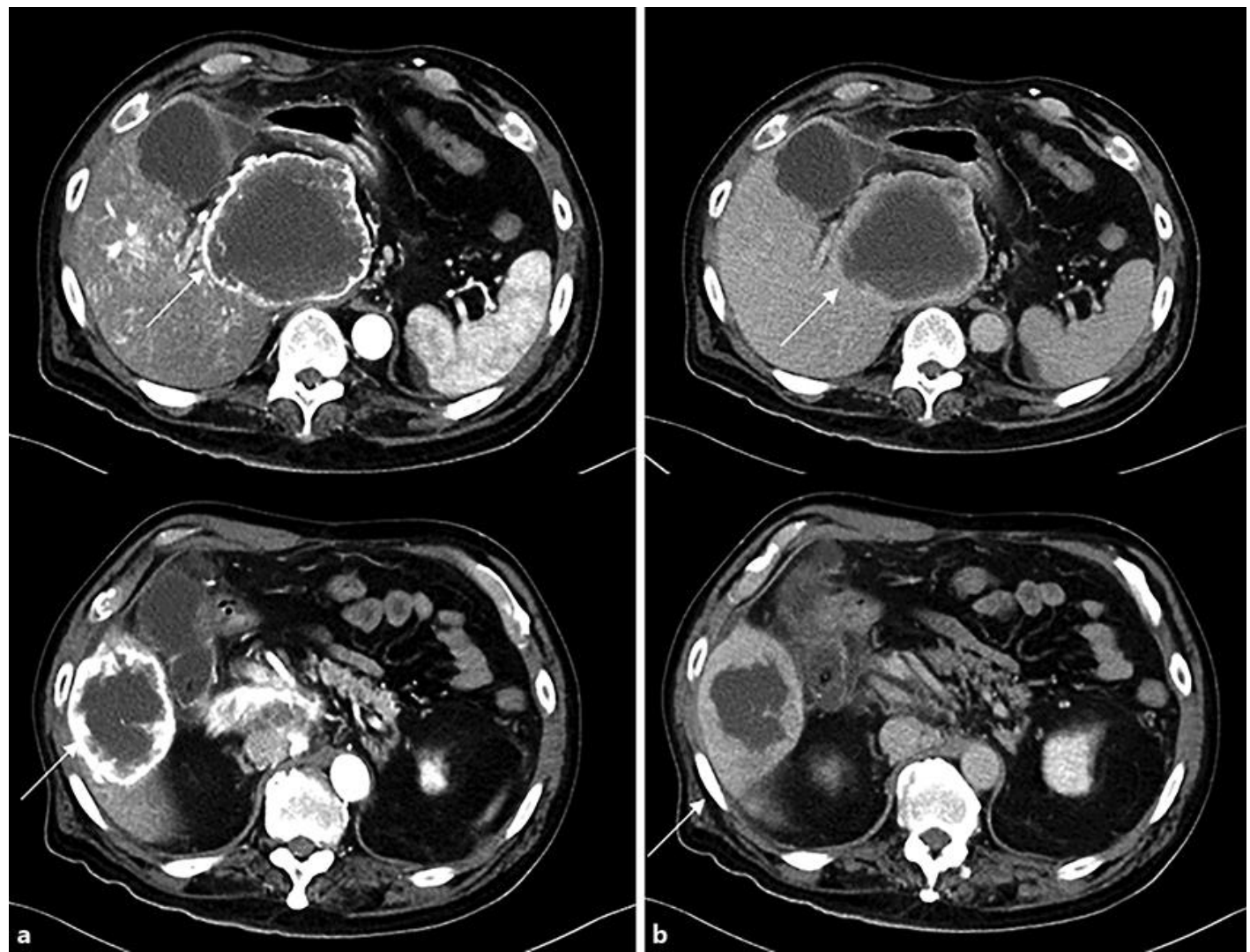

Fig. 2. a Computed tomography revealed that the liver tumors in the right and the caudal lobes were marginally contrasted in high density in the early phase. b Both liver tumors were contrasted in iso-density in the late phase. Arrows indicate the liver tumors. 


\section{Case Reports in Gastroenterology}

\begin{tabular}{l|l}
\hline Case Rep Gastroenterol 2019;13:58-65 \\
\hline DOI: 10.1159/000495604 & $\begin{array}{l}\text { @ 2019 The Author(s). Published by S. Karger AG, Basel } \\
\text { www.karger.com/crg }\end{array}$ \\
\hline
\end{tabular}

Tashiro et al.: Primary Gastrointestinal Stromal Tumor of the Liver with Cystic Changes
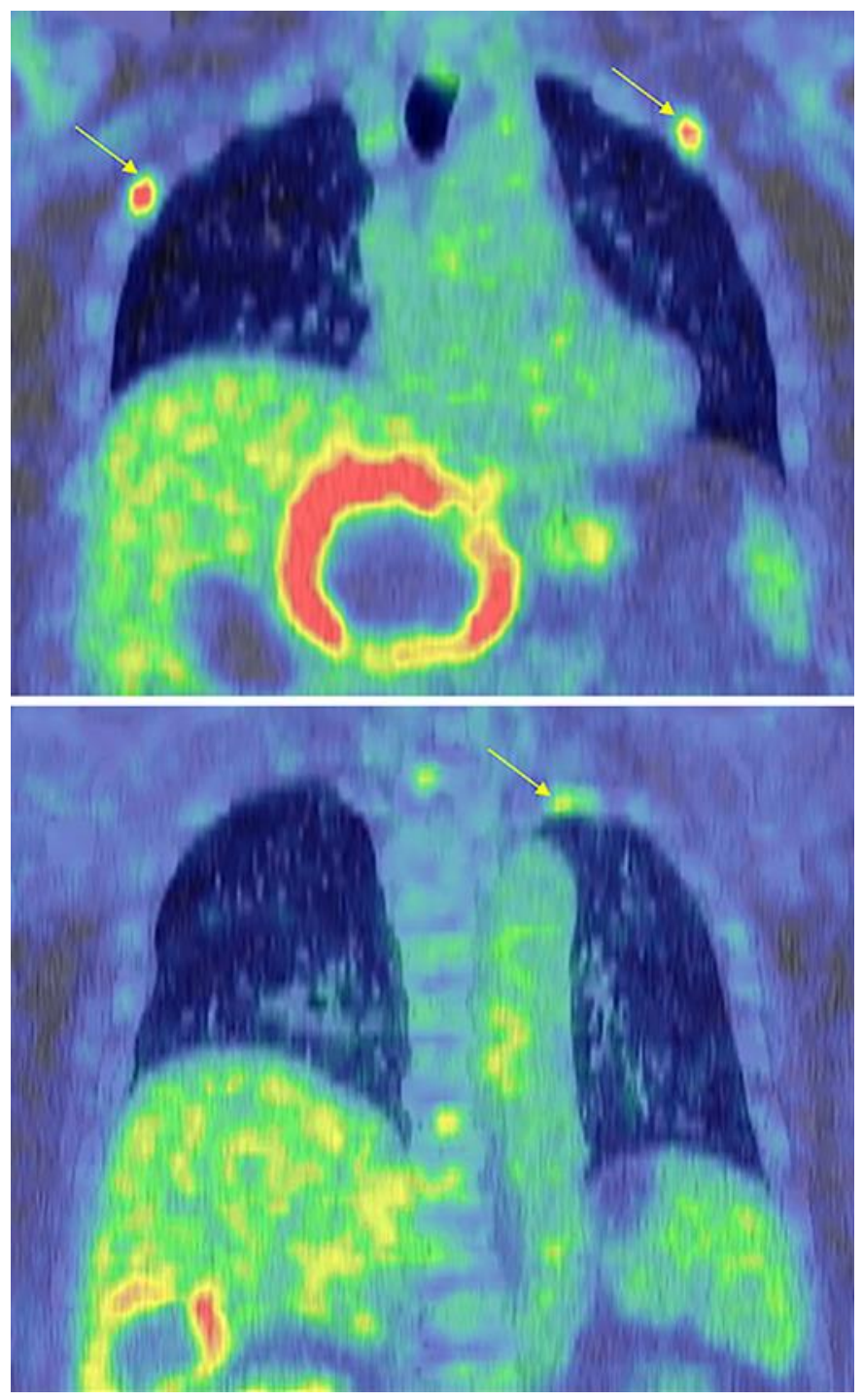

Fig. 3. $\left[{ }^{18} \mathrm{~F}\right]$-fluoro-2-deoxy-D-glucose (FDG)-positron emission tomography revealed not only focal FDG uptake in the liver tumors but also multiple focal FDG uptakes in bones. Arrows indicate focal FDG uptakes in bones. 


\section{Case Reports in Gastroenterology}

\begin{tabular}{l|l}
\hline Case Rep Gastroenterol 2019;13:58-65 \\
\hline DOI: 10.1159/000495604 & $\begin{array}{l}\text { @ 2019 The Author(s). Published by S. Karger AG, Basel } \\
\text { www.karger.com/crg }\end{array}$ \\
\hline
\end{tabular}

Tashiro et al.: Primary Gastrointestinal Stromal Tumor of the Liver with Cystic Changes
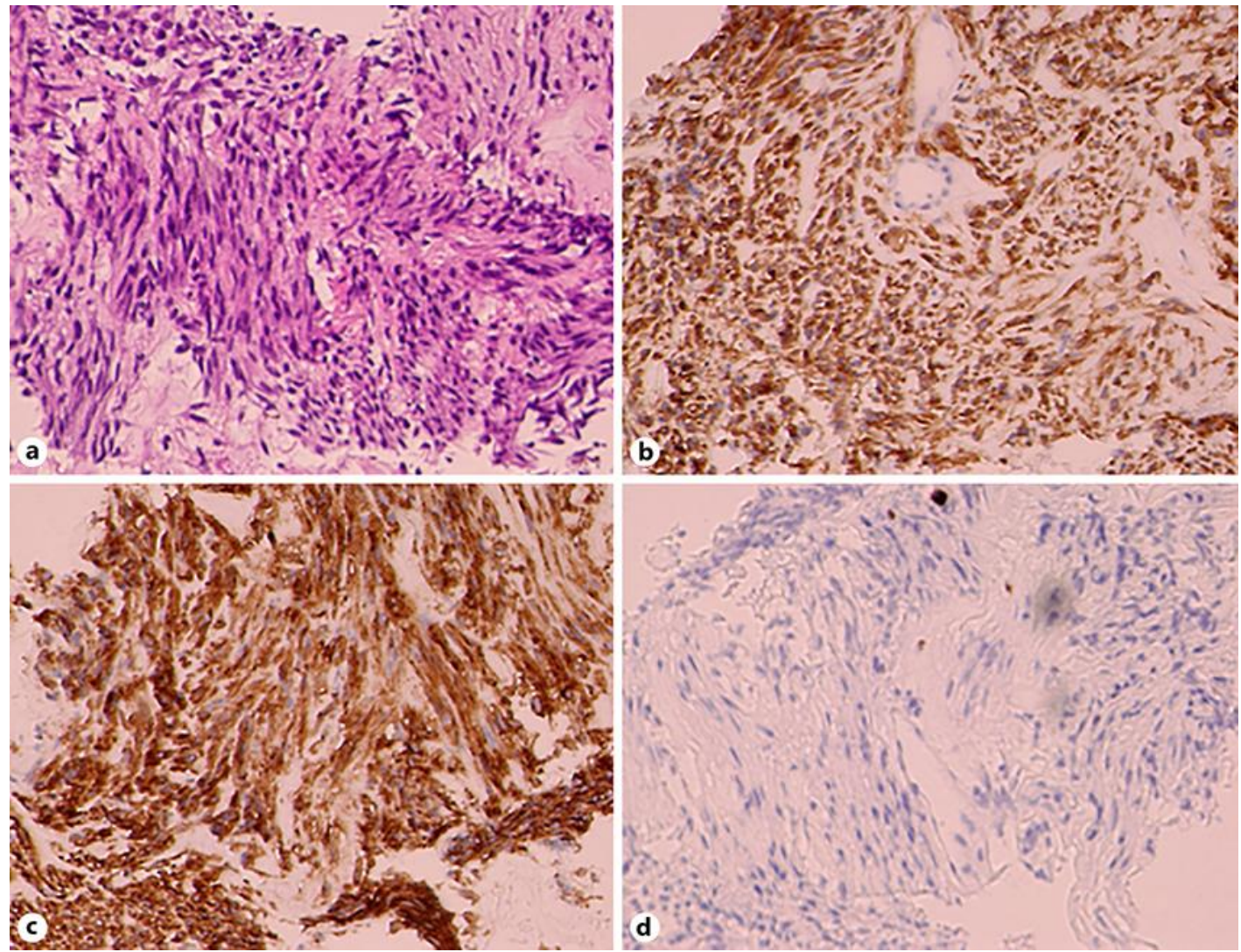

Fig. 4. a Hematoxylin and eosin staining showed that the liver tumor was composed of spindle cells with pleomorphic nuclei arranged into short fascicles. $\mathbf{b}$ The immunohistochemical staining for c-Kit was positive. $\mathbf{c}$ The immunohistochemical staining for DOG1 was positive. $\mathbf{d}$ The immunohistochemical staining for control was negative. Original magnification, $\times 200$. 